Article

\title{
Novel Yeast Strains for the Efficient Saccharification and Fermentation of Starchy By-Products to Bioethanol
}

\author{
Nicoletta Gronchi, Lorenzo Favaro *(1), Lorenzo Cagnin, Silvia Brojanigo, Valentino Pizzocchero, \\ Marina Basaglia and Sergio Casella \\ Department of Agronomy, Food, Natural resources, Animals and the Environment (DAFNAE), University of \\ Padova, Agripolis, 35020 Legnaro (PD), Italy; nicoletta.gronchi@studenti.unipd.it (N.G.); \\ lorenzocagnin@gmail.com (L.C.); silvia.brojanigo@gmail.com (S.B.); valentino.pizzocchero@unipd.it (V.P.); \\ marina.basaglia@unipd.it (M.B.); sergio.casella@unipd.it (S.C.) \\ * Correspondence: lorenzo.favaro@unipd.it; Tel.: +39-049-8272800; Fax: +39-049-8272929
}

Received: 16 January 2019; Accepted: 19 February 2019; Published: 22 February 2019

\begin{abstract}
The use of solid starchy waste streams to produce value-added products, such as fuel ethanol, is a priority for the global bio-based economy. Despite technological advances, bioethanol production from starch is still not economically competitive. Large cost-savings can be achieved through process integration (consolidated bioprocessing, CBP) and new amylolytic microbes that are able to directly convert starchy biomass into fuel in a single bioreactor. Firstly, CBP technology requires efficient fermenting yeast strains to be engineered for amylase(s) production. This study addressed the selection of superior yeast strains with high fermentative performances to be used as recipient for future CBP engineering of fungal amylases. Twenty-one newly isolated wild-type Saccharomyces cerevisiae strains were screened at $30{ }^{\circ} \mathrm{C}$ in a simultaneous saccharification and fermentation (SSF) set up using starchy substrates at high loading $(20 \% \mathrm{w} / \mathrm{v})$ and the commercial amylases cocktail STARGEN ${ }^{\mathrm{TM}}$ 002. The industrial yeast Ethanol Red ${ }^{\mathrm{TM}}$ was used as benchmark. A cluster of strains produced ethanol levels (up to $118 \mathrm{~g} / \mathrm{L}$ ) significantly higher than those of Ethanol $\operatorname{Red}^{\mathrm{TM}}$ (about $109 \mathrm{~g} / \mathrm{L}$ ). In particular, S. cerevisiae L20, selected for a scale-up process into a 1-L bioreactor, confirmed the outstanding performance over the industrial benchmark, producing nearly $101 \mathrm{~g} / \mathrm{L}$ ethanol instead of $94 \mathrm{~g} / \mathrm{L}$. As a result, this strain can be a promising CBP host for heterologous expression of fungal amylases towards the design of novel and efficient starch-to-ethanol routes.
\end{abstract}

Keywords: ethanol; starchy waste; natural yeast strains; consolidated bioprocessing; broken rice

\section{Introduction}

In the near future, the non-renewable resources such as crude oil, coal and natural gases, that collectively account for about $82 \%$ of global energy needs [1], will no longer be viable. Therefore, the global communities are moving toward the search for reducing fossil oil dependence and long-term sustainable forms of energies such as biofuels [2-6].

Among liquid biofuels, bioethanol has emerged as a clean and eco-friendly fuel that could replace gasoline, both as pure ethanol in specially designed engines, or most widely as blends with fossil gasoline ranging from 5 to $20 \%$ (also referred to as E5 or E20) [1,7,8]. Although the energy equivalent of ethanol as fuel is $66 \%$ than petroleum, its combustion is $15 \%$ more efficient because of higher oxygen content and less exhaust emissions, such as sulfur and nitrogen oxides, are produced [9]. It has been estimated that the use of $10 \%$ ethanol blends could reduce greenhouse gasses emissions by $12-19 \%$ compared to conventional fossil fuel [10]. 
In Brazil and US, the leading producers, first generation bioethanol is obtained from sugarcane or corn starch, respectively. However, since bioethanol market is expanding further, a good strategy is to look for alternative feedstocks that do not compete with food supplies [11]. In this perspective, biomasses are accounted as the fourth largest source of energy on Earth [1,12] and it is expected that the only foreseeable primary source that could provide adequate fuel supplies for transportation sector is waste biomass [13]. Before being processed to any added-valued compounds, solid waste streams have to be carefully managed through the promotion of safe practices and effective technologies, such as source separation, biological treatment and supply chain development to ensure the overall economic feasibility of the process. A wide variety of waste organic materials, like residues from agricultural, forest and industrial processing as well as the organic fraction of municipal solid waste, actually contains considerable amounts of fermentable glucose, as monomers or polymers (i.e., starch, cellulose), that have been used for biofuels, biopolymers and enzymes production [14-20].

Lignocellulosic biomasses are the most promising raw materials considering their great availability and limited cost $[11,21,22]$. Along with lignocellulose, starchy waste streams with high starch content could be exploited for bioethanol production [23-27].Indeed, starch is the most abundant form of energy storage in plants. The structure can vary regarding the botanical species (starch content can range from 50 to $90 \%$ in cereals, tubers and roots) and represents a high-yielding ethanol resource $[2,9,28]$.

The current industrial process of starch conversion into bioethanol, involves four steps: (I) liquefaction at high temperatures $\left(80-100^{\circ} \mathrm{C}\right.$ ), (II) saccharification into glucose by thermostable $\alpha$-amylases and glucoamylases, (III) microbial fermentation to ethanol and (IV) alcohol distillation and dehydration [29]. However, the global-scale application is hampered by high cost processing. The feedstock (corn) is considered as the main share $(60 \%)$ followed by processing expenditures $(10-20 \%)$. To ensure the economic feasibility of the overall process, the substitution of corn with cheaper biomasses together with improved process integrations have been proposed $[9,30]$. The total cost expenditure to produce bioethanol from starch could be reduced by consolidated bioprocessing (CBP) configuration and by using a single microorganism able to both secrete hydrolytic enzymes and ferment the resulting sugars in a single reactor [31,32]. The advantages include the direct utilization of raw starch without pre-treatment steps, eliminating the cost for energy inputs, exogeneous enzymes, maximizing the ethanol yield and minimizing by-product formation [33].

To date, no natural microorganism is available to perform CBP. Genome engineering, such as heterologous gene expression, is fundamental to create a new microbial biocatalyst to be used at industrial scale for the starch-to-ethanol processing [31]. In S. cerevisiae, heterologous gene expression is well established. Several amylase genes have been expressed for starch conversion, mainly in laboratory strains and, lately, also in natural and industrial strains [34-37]. However, the conversion rate of raw feedstocks or high substrate loading was not relevant for industrial scale. Even though good progresses have been done, the major challenge is the co-production of both amylases and glucoamylases at optimal levels to achieve high volumetric activities. The effective conversion of raw starch in a short timeframe could be competitive only if the fermentation abilities of the strain are not affected in terms of ethanol yield and starch utilization [32,35,38,39].

This study looked for novel S. cerevisiae strains with superior fermenting abilities to be used as host strains for heterologous expression of novel fungal hydrolytic enzymes with the final aim of developing efficient CBP yeast. A collection of wild-type strains, newly isolated from a winery, has been evaluated for fermentative performances at $30^{\circ} \mathrm{C}$ under SSF regime of high substrate loading $(20 \% \mathrm{w} / \mathrm{v})$ of starchy materials. A commercial mix of $\alpha$-amylase and glucoamylase, STARGEN ${ }^{\mathrm{TM}}$ 002, was used at optimized doses to perform starch hydrolysis. The S. cerevisiae Ethanol Red ${ }^{\mathrm{TM}}$ strain, currently applied in first and second generation bioethanol plants, served as benchmark [37].

Broken rice, where starch accounts up to $87.5 \%$ of dry matter, has been adopted as a model of several agricultural and industrial wastes mainly composed by starch [9]. It is one of the most abundant waste streams of rice processing with more than 45 million tons globally produced per 
year [40]. Such enormous amount of cheap biomass would be directly accessible and/or collectable at rice processing sites [24]. Raw corn starch (Sigma-Aldrich, Milano, Italy) was used as control feedstock.

\section{Results and Discussion}

\subsection{Isolation, Genetic Characterization and Fermentative Abilities of Novel Yeast Strains in Glucose}

With the final aim of isolating and selecting strains with high fermenting performances from glucose, the winery background was chosen since it is related to ethanol production and yeast are expected to produce and tolerate high alcohol concentrations. Yeast strains were isolated from grape marcs and incubated on Wallerstein Laboratory (WL) plates at $30{ }^{\circ} \mathrm{C}$. Twenty-one isolates were classified as $\mathrm{S}$. cerevisiae and first screened for their ability to consume glucose at $30{ }^{\circ} \mathrm{C}$ in must nutritive synthetic (MNS) minimal medium supplemented with $200 \mathrm{~g} / \mathrm{L}$ glucose, as such concentration is typical of the first generation ethanol plants after saccharification of corn [38].

Due to their relatively different phenotypic backgrounds, seven control strains of $S$. cerevisiae were included in this research as benchmarks (Table 1). Three of these reference strains, namely S. cerevisiae Fm17, M2n and MEL2, have been already exploited for ethanol production from different lignocellulosic and starchy substrates [18,32,41,42], whereas three additional strains (S. cerevisiae HR4, WL3, YI30), recently characterized for their inhibitors tolerance and fermenting abilities [43], were included as additional controls. Finally, S. cerevisiae Ethanol Red ${ }^{\mathrm{TM}}$ was considered as industrial reference strain, widely applied in both first and second generation ethanol applications [37].

Table 1. S. cerevisiae strains used in this study.

\begin{tabular}{ccc}
\hline S. cerevisiae Strains & Relevant Phenotype and Origin & Source/Reference \\
\hline L1-L21 & wild-type & This study \\
Ethanol Red & industrial strain & Fermentis \\
Fm17 & wild-type strain with high lignocellulosic inhibitors tolerance & {$[41]$} \\
M2n & distillery strain & {$[32]$} \\
MEL2 & wild type strain from grape marcs & {$[42]$} \\
HR4 & wild-type strain from wine fermentations & {$[43]$} \\
WL3 & wild-type strain from wine fermentations & {$[43]$} \\
YI30 & wild-type strain from wine fermentations & {$[43]$} \\
\hline
\end{tabular}

In this project, the ability of the yeast to utilize glucose was determined as fermenting vigour and expressed in terms of grams of glucose consumed per L of MNS medium, as described in Materials and Methods. Overall, both newly selected isolates and control strains exhibited high and comparable level of fermenting vigour (Figure 1). The newly isolated strains S. cerevisiae L1, L2, L5, L7, L8, L9 and L21, were not included as their fermenting abilities were lower than those of the benchmark strain M2n, displaying the bottom fermenting vigour.

Once incubated in $200 \mathrm{~g} / \mathrm{L}$ glucose, few isolates quickly consumed all the sugar within 15 days (Figure 1). Among them, S. cerevisiae L6, L14, L15, L16 and L20 demonstrated outstanding fermentative vigour. Interestingly, their ability outperformed those reported for S. cerevisiae MEL2 and S. cerevisiae Ethanol Red ${ }^{\mathrm{TM}}$, which showed the most favorable vigour among the reference yeast strains. Moreover, the selected newly isolated strains disclosed fermentative efficiency higher than those recently described from high glucose concentrations by several S. cerevisiae yeast $[42,44,45]$. As such, the fermenting capabilities of the novel yeast strains are promising considering also the medium adopted to screen for fermenting vigour. MNS broth, when compared with the formulation of other commonly used defined media [46,47], has indeed the lowest levels of components, macro and micro-nutrients. Therefore, yeast able to grow rapidly and efficiently ferment under nutrient limitation should be considered very interesting for bioethanol industrial scale applications. To further assess their aptitude to ferment starchy substrates under SSF configurations, representative of starch-to-ethanol processes, the novel collection of yeast has been adopted to produce ethanol from broken rice and raw corn starch. 


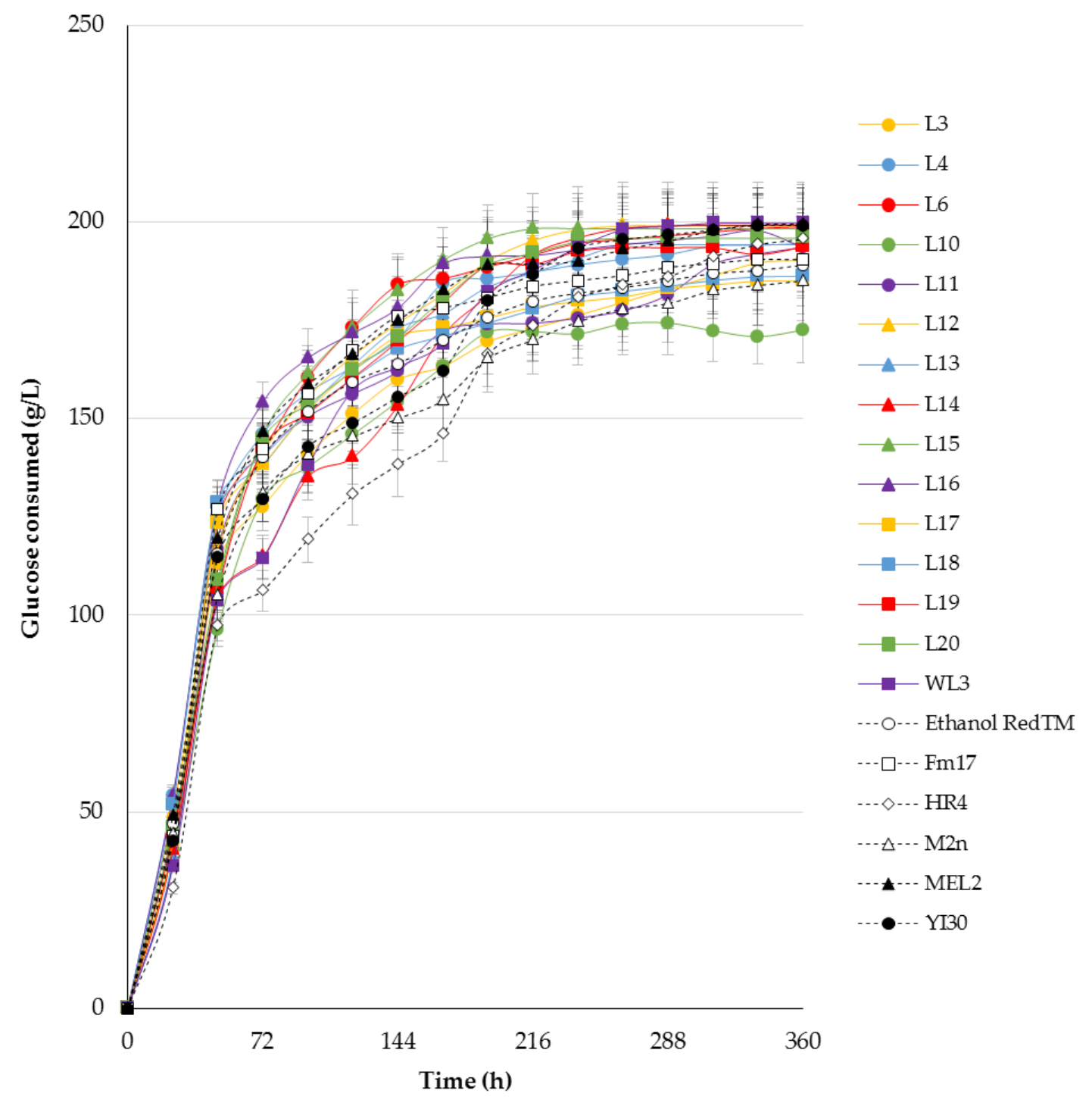

Figure 1. Cumulative sugar utilization (g/L) of S. cerevisiae strains in MNS medium with $200 \mathrm{~g} / \mathrm{L}$ glucose. The experiment was conducted in triplicate $( \pm \mathrm{SD})$.

\subsection{Fermentative Abilities under SSF Setting on Starchy Materials}

The fermentative vigour of all the strains was then evaluated on broken rice and raw corn starch at high substrate loading $(20 \% \mathrm{w} / \mathrm{v})$ under oxygen-limited conditions at $30{ }^{\circ} \mathrm{C}$. The commercial mixture of amylases STARGEN ${ }^{\mathrm{TM}} 002$ was supplied to support starch saccharification. Based on the assumptions that one gram of starch is equivalent to $1.11 \mathrm{~g}$ of glucose [48], the final theoretical glucose concentration achievable by complete saccharification of $20 \% \mathrm{w} / \mathrm{v}$ of starchy materials was 194 and $235 \mathrm{~g} / \mathrm{L}$ of YNB containing $20 \% \mathrm{w} / \mathrm{v}$ of broken rice and corn starch, respectively.

Owing to the great volume of data generated, total cumulative glucose consumption (Figure 2) and fermentation parameters (Table 2) are reported only for the best ten fermenting strains (namely L11, L12, L13, L15, L16, L17, L18, L19 and L20) as well as for the top performing benchmark yeast S. cerevisiae WL3 and Ethanol Red ${ }^{\mathrm{TM}}$. 


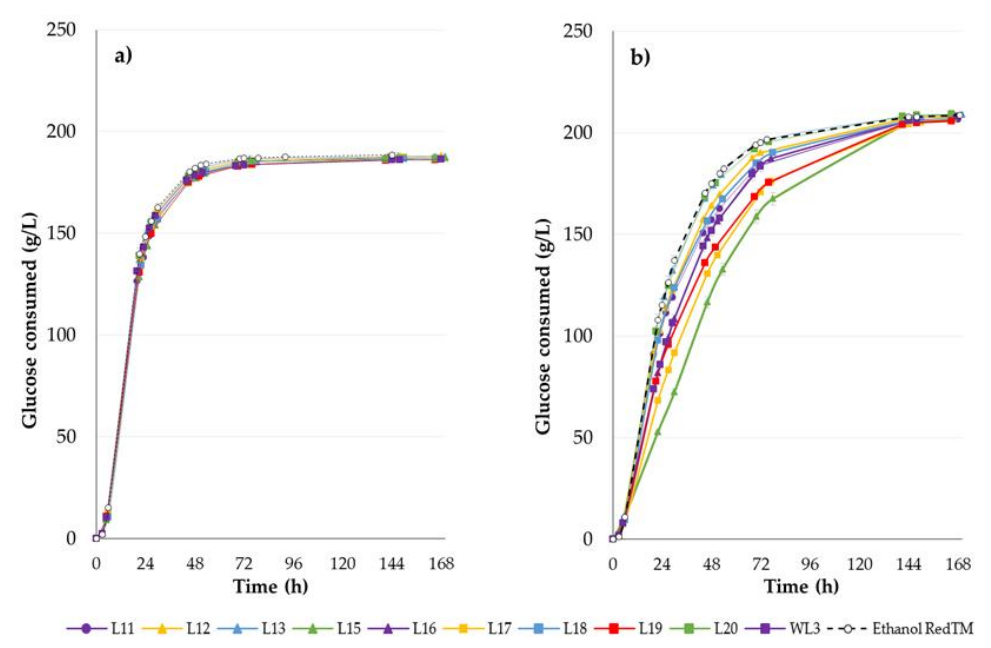

Figure 2. Cumulative sugar utilization (g/L) of S. cerevisiae strains at $30{ }^{\circ} \mathrm{C}$ in $\mathrm{YNB}$ medium with $20 \%$ $\mathrm{w} / \mathrm{v}$ (a) broken rice or (b) raw corn starch in the presence of STARGEN ${ }^{\mathrm{TM}} 002$. The experiment was conducted in triplicate $( \pm \mathrm{SD})$.

In the presence of broken rice, all the selected strains performed comparably and only slight differences in fermenting vigour could be appreciated between the newly isolated and the benchmarks (Figure 1a). The highest glucose consumption on broken rice was approximately $97 \%$ of the theoretical content (188 g for L18 and L20 out of $194 \mathrm{~g} / \mathrm{L}$ ). Furthermore, broken rice was confirmed to be a promising material for ethanol production [24] with more than $100 \mathrm{~g} / \mathrm{L}$ of ethanol produced (Table 2). Nevertheless, this substrate was not suitable for strain selection, since no significant differences, at least in terms of fermenting vigour, were evident among the tested strains. This could be ascribed to the native high amount of simple sugars (mainly glucose, fructose and sucrose) and proteins $(8.5 \%$ DM) of broken rice (see Materials and Methods), which could have enhanced and supported the fermenting activities.

On the contrary, raw corn starch, with very limited values of protein $(0.3 \% \mathrm{DM}$, see Table 4$)$ and no free sugars available, demonstrated to be a useful feedstock to screen for the most promising yeast strains. As reported in Figure 1b, indeed, the ten selected novel yeast strains showed comparable but different levels of fermenting vigour. Overall, only about $85 \%$ of glucose theoretically obtainable by saccharification of raw corn starch was used ( $200 \mathrm{~g}$ of glucose out of $235 \mathrm{~g} / \mathrm{L}$ ). Noteworthy, a small number of strains, including L13 (up to $208.9 \mathrm{~g} / \mathrm{L}$ ), L20 (up to $206.5 \mathrm{~g} / \mathrm{L}$ ) and WL3 (up to $207.9 \mathrm{~g} / \mathrm{L}$ ), performed very similarly to Ethanol Red ${ }^{\mathrm{TM}}$, which clearly reaffirmed its great ability to consume glucose $(208.7 \mathrm{~g} / \mathrm{L})$ (Figure $2 \mathrm{~b})$. The strains demonstrating a glucose consumption significantly lower than Ethanol $\operatorname{Red}^{\mathrm{TM}}$ were not considered as proficient fermenting yeast.

The ethanol yield, glucose and glycerol content of SSF experiments after $120 \mathrm{~h}$ are reported in Table 2. Only minimal amounts of residual glucose were observed in few spent fermentation broths (Table 2), indicating that the majority of the strains were able to completely utilize the sugar. The cluster of selected strains produced ethanol levels significantly greater than Ethanol Red ${ }^{\mathrm{TM}}$ from both broken rice and raw corn starch. This means that the industrial yeast $S$. cerevisiae Ethanol Red ${ }^{\mathrm{TM}}$, although presenting the fastest glucose consumption rates (Figure 1), was outperformed in terms of ethanol yield by all the selected novel strains as well as by the benchmark S. cerevisiae WL3, recently reported for promising fermenting performances [43]. Glycerol was detected as a common secondary fermentation product. According to what is reported for vinification, the concentrations of glycerol were found to be nearly 10 times smaller than the ethanol produced [49]. To increase ethanol production as biofuel, it is fundamental to minimize glycerol formation to better redirect the carbon flux towards ethanol. Interestingly, all newly isolated strains together with the reference S. cerevisiae WL3 produced glycerol at comparable levels from both broken rice and raw corn starch confirming their great ability to rapidly convert glucose into ethanol. On the contrary S. cerevisiae Ethanol Red ${ }^{\mathrm{TM}}$ showed the highest glycerol 
production when SSF was conducted on raw starch and high glycerol levels comparatively to ethanol produced also from broken rice (Table 2).

Table 2. Ethanol, glucose and glycerol content of SSF experiment at $30^{\circ} \mathrm{C}$ using as substrate broken rice or raw corn starch. The substrate loading for each experiment was $20 \%(\mathrm{w} / \mathrm{v})$. The experiment was conducted in triplicate $( \pm \mathrm{SD}) . \Upsilon_{E / S}, \%$ of theoretical maximum ethanol yield per gram of glucose equivalent available.

\begin{tabular}{|c|c|c|c|c|c|c|c|c|}
\hline \multirow[b]{2}{*}{ Strain } & \multicolumn{4}{|c|}{ Broken Rice } & \multicolumn{4}{|c|}{ Raw Corn Starch } \\
\hline & $\begin{array}{l}\text { Residual } \\
\text { Glucose } \\
\text { (g/L) }\end{array}$ & $\begin{array}{c}\text { Glycerol } \\
\text { (g/L) }\end{array}$ & $\begin{array}{c}\text { Ethanol } \\
\text { Concentration } \\
(\mathrm{g} / \mathrm{L})\end{array}$ & $Y_{E / S}$ & $\begin{array}{l}\text { Residual } \\
\text { Glucose } \\
\text { (g/L) }\end{array}$ & $\begin{array}{l}\text { Glycerol } \\
\text { (g/L) }\end{array}$ & $\begin{array}{c}\text { Ethanol } \\
\text { Concentration } \\
(\mathrm{g} / \mathrm{L})\end{array}$ & $Y_{E / S}$ \\
\hline Ethanol Red ${ }^{\mathrm{TM}}$ & - & $8.83 \pm 0.12$ & $101.05 \pm 0.54$ & 91 & $0.30 \pm 0.06$ & $10.05 \pm 0.17$ & $109.36 \pm 0.33$ & 86 \\
\hline L11 & - & $8.75 \pm 0.02$ & $107.70 \pm 0.44$ & 97 & $1.68 \pm 0.28$ & $9.19 \pm 0.20$ & $116.07 \pm 0.06$ & 91 \\
\hline L12 & $0.58 \pm 0.14$ & $9.03 \pm 0.03$ & $108.39 \pm 1.22$ & 98 & $0.82 \pm 0.65$ & $9.21 \pm 0.19$ & $116.22 \pm 1.97$ & 91 \\
\hline L13 & $0.62 \pm 0.01$ & $9.45 \pm 0.18$ & $107.15 \pm 0.28$ & 97 & $1.55 \pm 0.76$ & $9.63 \pm 0.04$ & $116.12 \pm 0.96$ & 91 \\
\hline L15 & - & $8.90 \pm 0.06$ & $107.43 \pm 0.16$ & 97 & - & $8.24 \pm 0.08$ & $117.17 \pm 0.08$ & 92 \\
\hline L16 & - & $8.93 \pm 0.04$ & $107.77 \pm 0.21$ & 97 & - & $9.25 \pm 0.15$ & $117.93 \pm 0.14$ & 92 \\
\hline L17 & - & $8.36 \pm 0.02$ & $107.16 \pm 0.66$ & 97 & - & $8.53 \pm 0.01$ & $116.78 \pm 0.42$ & 92 \\
\hline L18 & - & $7.79 \pm 0.05$ & $106.73 \pm 0.34$ & 96 & - & $8.45 \pm 0.09$ & $117.35 \pm 1.06$ & 92 \\
\hline L19 & - & $8.25 \pm 0.08$ & $107.32 \pm 0.25$ & 97 & - & $8.60 \pm 0.11$ & $116.44 \pm 0.21$ & 91 \\
\hline L20 & - & $8.17 \pm 0.14$ & $107.19 \pm 0.15$ & 97 & - & $7.97 \pm 0.09$ & $116.98 \pm 1.73$ & 92 \\
\hline WL3 & $0.30 \pm 0.01$ & $9.16 \pm 0.12$ & $106.17 \pm 0.36$ & 96 & $0.29 \pm 0.04$ & $9.60 \pm 0.07$ & $115.05 \pm 0.24$ & 90 \\
\hline
\end{tabular}

Taken together the experiments on fermenting vigour from glucose (Figure 1) and SSF configurations with broken rice and raw starch as substrates (Figure 2 and Table 2) indicated that the newly isolated strains have great potential as ethanol producers, with performances even higher than those exhibited by several benchmark yeast strains. More specifically, S. cerevisiae L20 displayed one of the most outperforming phenotypes, especially in the early stage of fermentation, and was then selected for further fermentation experiments at bioreactor scale.

\subsection{Scale-up in 1-L Bench Fermenter}

S. cerevisiae $\mathrm{L} 20$ together with the reference Ethanol Red ${ }^{\mathrm{TM}}$ have been investigated for SSF in 1-L bench reactor using $20 \% \mathrm{w} / \mathrm{v}$ of either broken rice or raw corn starch (Figure 3). When broken rice was used as feedstock, the fermentation trend was similar for both strains (Figure 3). Interestingly, the strains produced comparable ethanol levels (about $86 \mathrm{~g} / \mathrm{L}$ ) after $72 \mathrm{~h}$ of fermentation. Nevertheless, the novel strain displayed ethanol performances always better than those of Ethanol Red ${ }^{\mathrm{TM}}$, particularly after $24 \mathrm{~h}$ of SSF (Table 3), with a maximum productivity of $3.10 \mathrm{~g} / \mathrm{L} / \mathrm{h}$, which was 1.10 -fold than that of the industrial benchmark $(2.83 \mathrm{~g} / \mathrm{L} / \mathrm{h})$. Such ethanol productivity values are of great interest and potential application [39]. Moreover, final ethanol yields were also higher, with the novel strain displaying $86 \%$ of the maximum theoretical instead of $83 \%$ detected for S. cerevisiae Ethanol Red ${ }^{\mathrm{TM}}$.

On raw starch, S. cerevisiae L20 confirmed to be a promising strain (Figure 3a and Table 3), with almost $101 \mathrm{~g} / \mathrm{L}$ ethanol produced within $72 \mathrm{~h}$ of incubation. On the contrary, as reported in Figure $3 \mathrm{~b}$ and Table 3, the industrial yeast produced lower alcohol values (up to $94 \mathrm{~g} / \mathrm{L}$ ). Fermenting parameters were again much better for S. cerevisiae L20 (Table 3), with a maximum productivity of $3.20 \mathrm{~g} / \mathrm{L} / \mathrm{h}$, which was 1.33-fold higher than that of the industrial benchmark $(2.41 \mathrm{~g} / \mathrm{L} / \mathrm{h})$. Ethanol yields and carbon conversion values confirmed that the novel strain outperformed the industrial yeast further supporting both the saccharification of starch to glucose and then glucose-to-ethanol fermentation.

Overall, as reported in Table 3, ethanol levels and efficiencies obtained by the yeast strains from both substrates were found to be lower than those detected at smaller scale (Table 2). This finding could be due to an increase of viscosity of the medium which was found to limit the ethanol yield in up-scaling of high gravity SSF experiments on sweet potato [50] or to an increase of stress exposure linked to limited transportation and elimination of $\mathrm{CO}_{2}$, toxic metabolites and additional heat generated by agitation [51]. This calls for further experimental activities in order to optimize the scaling up of the 
process and is in agreement with lower ethanol yields recently obtained up-scaling the simultaneous liquefaction, saccharification and fermentation (SLSF) of broken rice at high gravity [52].
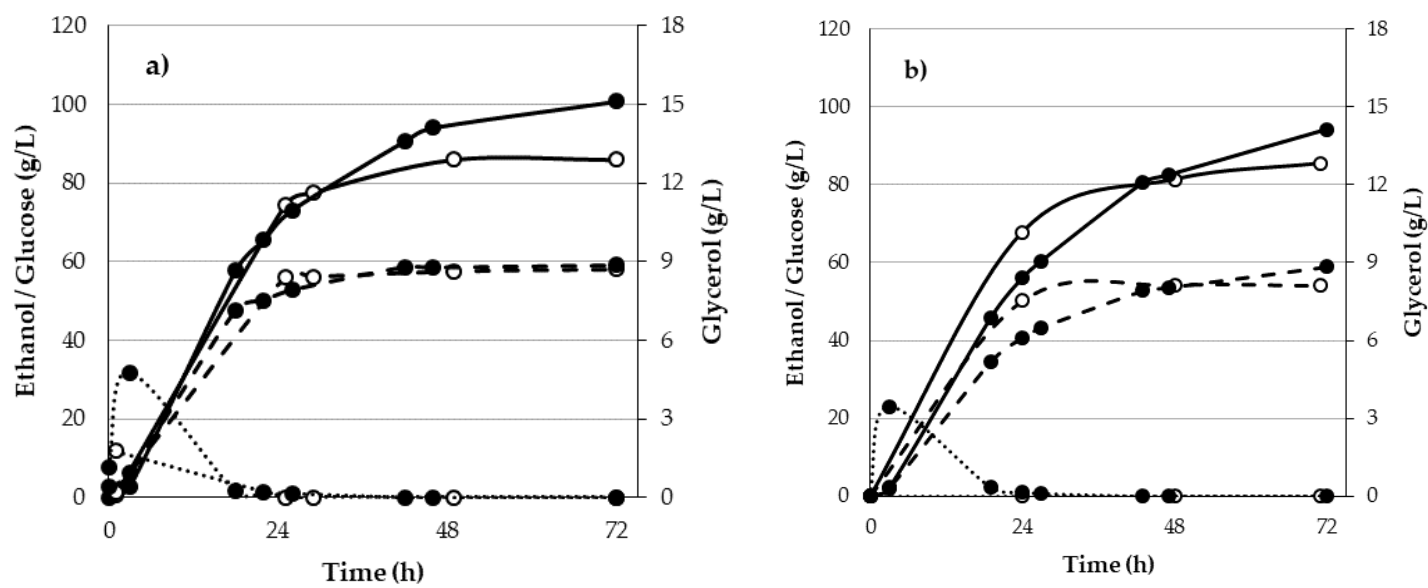

—Ethanol ….... Glucose - - -Glycerol

Figure 3. Ethanol, glucose and glycerol production by S. cerevisiae wild-type strains (a) L20 and (b) Ethanol $\operatorname{Red}^{\mathrm{TM}}$ during SSF in 1-L bioreactor with $20 \%(\mathrm{w} / \mathrm{v})$ of broken rice $(\bigcirc)$ and raw corn starch $(\bullet)$ The experiment was conducted in duplicate and average values are presented.

Table 3. Conversion of starchy substrates at bioreactor level to ethanol and by-products by S. cerevisiae L20 and Ethanol Red ${ }^{\mathrm{TM}}$ strains.

\begin{tabular}{|c|c|c|c|c|}
\hline Feedstock & \multicolumn{2}{|c|}{ S. cerevisiae $\mathrm{L} 20$} & \multicolumn{2}{|c|}{ S. cerevisiae Ethanol Red ${ }^{\mathrm{TM}}$} \\
\hline \multicolumn{5}{|c|}{ Broken rice $=$ a glucose equivalent of $198.55 \mathrm{~g} / \mathrm{L}$ and a total carbon available $(\mathrm{mol} \mathrm{C})$ of 6.62} \\
\hline Product $(\mathrm{g} / \mathrm{L})$ & $24 \mathrm{~h}$ & $72 \mathrm{~h}$ & $24 \mathrm{~h}$ & $72 \mathrm{~h}$ \\
\hline Glucose & nd & nd & nd & nd \\
\hline Glycerol & 8.40 & 8.70 & 7.54 & 8.12 \\
\hline Ethanol & 74.44 & 87.01 & 67.86 & 85.46 \\
\hline $\mathrm{CO}_{2}$ & 71.20 & 83.23 & 64.91 & 81.74 \\
\hline Total carbon & 5.13 & 5.96 & 4.67 & 5.84 \\
\hline $\begin{array}{l}\text { Carbon conversion } \\
\qquad(\mathrm{mol} \mathrm{C})\end{array}$ & $77 \%$ & $90 \%$ & $71 \%$ & $88 \%$ \\
\hline$Y_{E / S(\% \text { of theoretical })}$ & $73 \%$ & $86 \%$ & $67 \%$ & $83 \%$ \\
\hline$Q(\mathrm{~g} / \mathrm{L} / \mathrm{h})$ & 3.10 & 1.21 & 2.83 & 1.19 \\
\hline$Q_{\max }(\mathrm{g} / \mathrm{L} / \mathrm{h})$ & \multicolumn{2}{|c|}{3.10 after $24 \mathrm{~h}$} & \multicolumn{2}{|c|}{2.83 after $24 \mathrm{~h}$} \\
\hline \multicolumn{5}{|c|}{ Raw corn starch $=$ a glucose equivalent of $238.82 \mathrm{~g} / \mathrm{L}$ and a total carbon available $(\mathrm{mol} \mathrm{C})$ of 7.93} \\
\hline Product $(\mathrm{g} / \mathrm{L})$ & $24 \mathrm{~h}$ & $72 \mathrm{~h}$ & $24 \mathrm{~h}$ & $72 \mathrm{~h}$ \\
\hline Glucose & 1.04 & nd & 1.14 & nd \\
\hline Glycerol & 7.92 & 8.86 & 6.10 & 8.84 \\
\hline Ethanol & 73.10 & 100.84 & 56.02 & 94.20 \\
\hline $\mathrm{CO}_{2}$ & 69.92 & 96.46 & 53.58 & 90.10 \\
\hline Total carbon & 5.06 & 6.87 & 3.89 & 6.43 \\
\hline $\begin{array}{l}\text { Carbon conversion } \\
(\mathrm{mol} \mathrm{C})\end{array}$ & $64 \%$ & $86 \%$ & $49 \%$ & $81 \%$ \\
\hline$Y_{E / S}(\%$ of theoretical) & $60 \%$ & $83 \%$ & $46 \%$ & $77 \%$ \\
\hline$Q(\mathrm{~g} / \mathrm{L} / \mathrm{h})$ & 3.05 & 1.40 & 2.33 & 1.31 \\
\hline$Q_{\max }(\mathrm{g} / \mathrm{L} / \mathrm{h})$ & \multicolumn{2}{|c|}{3.20 after $18 \mathrm{~h}$} & \multicolumn{2}{|c|}{2.41 after $18 \mathrm{~h}$} \\
\hline
\end{tabular}

nd: not detected; $Y_{E / S}$, theoretical maximum ethanol yield per gram of glucose equivalent available. 


\section{Materials and Methods}

\subsection{Feedstocks and Commercial Enzymes}

Broken rice was obtained from La Pila (Isola della Scala, Verona, Italy), dried in a forced-air oven at $60{ }^{\circ} \mathrm{C}$ for $48 \mathrm{~h}$ and milled in a hammer mill to pass throughout a $1.25 \mathrm{~mm}$ screen. The raw material was stored at room temperature. Starch from corn (Sigma-Aldrich) was used as benchmark substrate for SSF. No pre-treatments were performed, and raw feedstocks were used as such. The composition in terms of starch and protein, determined according to international standard methods [53], is reported in Table 4. The content of fermentable sugars in broken rice, namely glucose, fructose and sucrose, were assessed at $11.5 \mathrm{~g} / \mathrm{Kg}$ on a total of sugars of $13 \mathrm{~g} / \mathrm{Kg}$.

Table 4. Composition of feedstocks used in this study.

\begin{tabular}{cccc}
\hline Feedstock & Dry Matter, DM (\%) & Protein (\% DM) & Starch (\% DM) \\
\hline Broken rice & 96.0 & 8.5 & 84.0 \\
Raw corn starch & 90.3 & 0.3 & 95.3 \\
\hline
\end{tabular}

The enzyme mix STARGENTM 002, kindly supplied by Genencor (DuPont-Danisco group, Itasca, IL, USA), is an optimized blend of Aspergillus kawachii $\alpha$-amylase expressed in Thricoderma reesei and glucoamylase from $T$. reesei that works synergistically to hydrolyze granular starch to glucose. The enzymatic activity is 570 Glucoamylase Unit (GAU)/g and specific gravity is $1.14 \mathrm{~g} / \mathrm{mL}$. STARGENTM 002 was used following the supplier's instructions (http://www.dupont.com/content/dam/dupont/products-and-services/industrialbiotechnology/documents/DuPont-STARGEN002-web-EN.pdf).

\subsection{Yeast Strains, Isolation and Genetic Identification}

A collection of twenty-one wild-type S. cerevisiae strains was isolated in 2013 from grape marcs of a winery in Melara (Rovigo, Italy) (Table 1). After a storage of 30 days at the winery, fifty grams of marcs were dispersed in $500 \mathrm{~mL}$ of sterile physiological water $(0.85 \% \mathrm{NaCl})$, plated, after appropriate decimal dilutions, on WL medium (Wallerstein Laboratory, Oxoid, Milano, Italy; g/L: yeast extract, 4; casein hydrolysate, 5; D-glucose, 50; $\mathrm{KH}_{2} \mathrm{PO}_{4}, 0.55 ; \mathrm{KCl}, 0.425 ; \mathrm{CaCl}_{2}, 0.125 ; \mathrm{MgSO}_{4}, 0.125$; $\mathrm{FeCl}_{3}, 0.0025 ; \mathrm{MnSO}_{4}, 0.0025$; bromocresol green, 0.022) containing $200 \mu \mathrm{g} / \mathrm{mL}$ chloramphenicol (Sigma-Aldrich, Italy) to contain bacterial growth and incubated at $30{ }^{\circ} \mathrm{C}$ for $72 \mathrm{~h}$. After isolation, yeast colonies were purified by growing on Yeast Peptone Dextrose (YPD; g/L: yeast extract, 10; peptone, 20; glucose, 20) at $30^{\circ} \mathrm{C}$ for $48 \mathrm{~h}$. Isolates were maintained at $-80{ }^{\circ} \mathrm{C}$ in YPD containing $20 \%(\mathrm{v} / \mathrm{v})$ glycerol.

Genetic identification was achieved by D1/D2 region sequence analysis. Amplification of D1/D2 domain was performed using primers NL1 (5'-GCA TAT CAA TAA GCG GAG GAA AAG-3') and NL4 (5'-GGT CCG TGT TTC AAG ACG G-3') according to the protocol described by Kurtzman and Robnett [54]. Amplification products were checked by 1\% agarose gel electrophoresis and then subjected to sequencing. Species identification was performed after BlastN alignment (http://blast. ncbi.nlm.nih.gov/Blast.cgi) of the obtained sequences with those present in the Gen-Bank public database. A minimum sequence similarity level of $98 \%$ was considered for species identification.

\subsection{Fermentative Abilities of S. cerevisiae Strains in MNS Broth Supplemented with $200 \mathrm{~g} / \mathrm{L}$ Glucose}

S. cerevisiae strains were assessed for their fermentative ability in MNS minimal medium $(\mathrm{g} / \mathrm{L}$ : $\left(\mathrm{NH}_{4}\right)_{2} \mathrm{SO}_{4}, 0.3 ;\left(\mathrm{NH}_{4}\right)_{2} \mathrm{HPO}_{4}, 0.3 ; \mathrm{KH}_{2} \mathrm{PO}_{4}, 1 ; \mathrm{MgSO}_{4} \cdot 7 \mathrm{H}_{2} \mathrm{O}, 0.5 ; \mathrm{NaCl}, 0.1 ;$ malic acid, 2 ; tartaric acid, 3. mg/L: biotin, 0.02; D-pantothenic acid, 0.4; myo-inositol, 2; nicotinic acid, 0.4; thiamine, 0.4; pyridoxine, $0.4 ; p$-aminobenzoic acid, $0.2 ; \mathrm{H}_{3} \mathrm{BO}_{3}, 0.5 ; \mathrm{CuSO}_{4} \cdot 5 \mathrm{H}_{2} \mathrm{O}, 0.04 ; \mathrm{KI}, 0.1 ; \mathrm{NaMoO}_{4} \cdot 2 \mathrm{H}_{2} \mathrm{O}, 0.2$; $\left.\mathrm{ZnSO}_{4} \cdot 7 \mathrm{H}_{2} \mathrm{O}, 0.4 ; \mathrm{FeCl}_{3} \cdot 6 \mathrm{H}_{2} \mathrm{O}, 0.4 ; \mathrm{CaCl}_{2} \cdot 2 \mathrm{H}_{2} \mathrm{O}, 100\right)$ supplemented with $200 \mathrm{~g} / \mathrm{L}$ glucose according to the method described by Favaro and colleagues [41]. MNS broth was specifically adopted as 
it can be considered quite similar to several poor industrial media $[47,55]$ and can resemble the pre-industrial scale composition of bioethanol broth, where mainly $\mathrm{MgSO}_{4} \cdot 7 \mathrm{H}_{2} \mathrm{O},\left(\mathrm{NH}_{4}\right)_{2} \mathrm{SO}_{4}$ and little amounts of corn steep liquor are generally added during the fermentation step [56,57]. The commercial strain Ethanol Red ${ }^{\mathrm{TM}}$ (Fermentis, Marcq-en-Baroeul, France), currently used for large scale bioethanol fermentation, was included as industrial benchmark together with other yeast strains recently reported for their high promise as bioethanol producers (Table 1).

In short, every glass serum bottle was filled with $100 \mathrm{~mL}$ of MNS medium and then sealed using rubber stoppers with a needle for the removal of $\mathrm{CO}_{2}$ produced during fermentation. Pre-cultures of S. cerevisiae strains, grown overnight into YPD broth, were collected, centrifuged and washed twice with sterile physiological water $(0.85 \% \mathrm{NaCl})$. Yeast cells were then inoculated, with an average cell concentration of $7.5 \times 10^{4}$ cells per $\mathrm{mL}$, into each serum bottle containing $100 \mathrm{~mL}$ MNS broth. The incubation was performed in static condition at $30^{\circ} \mathrm{C}$. The $\mathrm{pH}$ of medium was set at $3.5 \mathrm{using} \mathrm{KOH}$ $(5 \mathrm{M})$. Fermentative vigour was daily monitored by measuring weight loss due to $\mathrm{CO}_{2}$ production. Results were reported as grams of glucose utilized per L of MNS by using a conversion factor of 2.118 [55]. The experiments were carried out in triplicate.

\subsection{Fermentative Abilities of S. cerevisiae Strains on Starchy Materials}

All strains were screened for fermentative abilities in an SSF regime from broken rice and raw corn starch. Pre-cultures were prepared in YNB broth (with amino acids: Yeast Nitrogen Base $6.7 \mathrm{~g} / \mathrm{L}$; Sigma-Aldrich) with $2 \% \mathrm{w} / \mathrm{v}$ of glucose in Erlenmeyer flasks and incubated overnight at $30{ }^{\circ} \mathrm{C}$ on a rotatory shaker at $600 \mathrm{rpm}$. Small-scale SSFs were conducted in 120-mL serum bottles with $20 \%(\mathrm{w} / \mathrm{v})$ dry substrate and appropriate nitrogen source (YNB with amino acids: $6.7 \mathrm{~g} / \mathrm{L}$; Sigma-Aldrich) in a total volume of $100 \mathrm{~mL}$ of buffered medium (citrate buffer $0.1 \mathrm{M}$ at $\mathrm{pH} 4$ ). Yeast cells were inoculated at Optical Density (OD) value of 1 and ampicillin $(100 \mathrm{mg} / \mathrm{L})$ and streptomycin $(75 \mathrm{mg} / \mathrm{L})$ were added to prevent bacterial contamination. STARGEN ${ }^{\mathrm{TM}} 002$ was then supplemented at ten times the recommended dosage ( $11.4 \mathrm{~g} / \mathrm{kg}$ of substrate). Rubber stoppers were used to set up oxygen-limited conditions and a needle was inserted for $\mathrm{CO}_{2}$ removal. Serum-bottles were incubated at $30{ }^{\circ} \mathrm{C}$ on magnetic stirrer with agitation speed at $700 \mathrm{rpm}$. The experiments were carried out in triplicate.

The fermentative vigour was daily monitored as described above. Results were reported as grams of glucose utilized per liter of medium by a conversion factor of 2.118 [55]. Samples were withdrawn after 5 days, filtered through $0.22-\mu \mathrm{m}$ and analyzed for their content by high performance liquid chromatography (HPLC) as indicated in 'Analytical methods and calculations'.

\subsection{Scale-up of SSF in 1-L Bench Fermenter}

The most promising strain, exhibiting an outstanding fermentative performance at small scale SSF, together with the benchmark industrial yeast Ethanol Red ${ }^{\mathrm{TM}}$, was up-scaled in a 1-L bioreactor (Applikon Biotechnology, Schiedam, The Netherlands) with a working volume of $900 \mathrm{~mL}$. The BioXpert software version 1.13 (Applikon Biotechnology) was used for data acquisition.

The broth was the same used for small-scale SSF except for $\mathrm{pH}$, which was controlled at 4.0 using automatic titration of $1 \mathrm{M} \mathrm{NaOH}$ solution. To maintain oxygen-limited conditions, aeration was not supplied. Yeast cells were inoculated at OD value of 1 and the cultures were stirred at $300 \mathrm{rpm}$ and maintained at $30{ }^{\circ} \mathrm{C}$ with a heating blanket. All parameters were controlled by my-Control unit (Applikon Biotechnology). Samples were aseptically collected at regular intervals and kept at $-20^{\circ} \mathrm{C}$. Samples were filtered through $0.22-\mu \mathrm{m}$ and diluted for HPLC analysis performed as described below.

\subsection{Analytical Methods and Calculations}

Samples from small scale fermentation and bioreactor experiments were analysed for their content in glucose, glycerol and ethanol trough liquid chromatography using a Shimadzu Nexera HPLC system, equipped with a RID-10A refractive index detector (Shimadzu, Kyoto, Japan). The chromatographic separations were performed using a Rezex ROA-Organic Acid H+ $(8 \%)$ column $(300 \mathrm{~mm} \times 7.8 \mathrm{~mm}$, 
Phenomenex, Torrance, CA, USA). The column temperature was set at $60^{\circ} \mathrm{C}$ and the analysis was performed at a flow rate of $0.6 \mathrm{~mL} / \mathrm{min}$ using isocratic elution, with $2.5 \mathrm{mM} \mathrm{H}_{2} \mathrm{SO}_{4}$ as a mobile phase [58].

The ethanol yield, $Y_{E / S}$, (g of ethanol/g of utilized glucose equivalent) was determined considering the amount of glucose equivalent available and compared to the maximum theoretical yield of $0.51 \mathrm{~g}$ of ethanol/g of consumed glucose equivalent.

The volumetric productivity $(Q)$ was intended as grams of ethanol per liter of culture per hour $(\mathrm{g} / \mathrm{L} / \mathrm{h})$ and the maximum volumetric productivity $\left(Q_{\max }\right)$ was defined as the highest volumetric productivity displayed by the $S$. cerevisiae strains. The theoretical $\mathrm{CO}_{2}$ yields were determined based on the ethanol produced by each yeast strain, assuming that equimolar ethanol and $\mathrm{CO}_{2}$ are produced. The percentage of carbon converted to glucose, ethanol, glycerol, and $\mathrm{CO}_{2}$ was calculated on a mole carbon basis.

Statistical analyses were assessed using the Graphpad Prism 5 package (Graphpad Software, Inc., San Diego, CA, USA). Descriptive statistics mean values and standard deviations were calculated. Data were analysed also by two ways factorial Analysis of Variance (ANOVA) with Duncan test.

\section{Conclusions}

Developing an amylolytic fermentative organism may overcome important limitations of starch-to-ethanol conversion. The production of alfa-amylases and glucoamylases at high titers still remains a major challenge, despite significant technological advances. By producing efficient amylolytic enzymes, the engineered yeast could reduce bioethanol costs and implement the large-scale biofuel production. Nonetheless, the fermenting yeast must have promising fermenting abilities under SSF configurations.

This paper was successful in selecting and characterizing a cluster of novel yeast strains with fermenting abilities even higher than those of $S$. cerevisiae Ethanol Red ${ }^{\mathrm{TM}}$, the most used yeast for first and second generation ethanol. Ethanol yields from glucose under simple fermentation and SSF settings were significantly improved in the case of the newly isolated strains. This finding is of great value considering that, to obtain great additional profits, first generation ethanol plants look for an increase of even $1 \%$ in ethanol yield.

Based on the fermentation studies, the collection of novel S. cerevisiae strains has great potential for future application in corn-to-ethanol processes. In particular, the selected yeast L20 could be considered as promising for the $\mathrm{CBP}$ of different starchy industrial residues and will be engineered for the expression of efficient amylolytic genes.

Author Contributions: N.G. participated in planning of the study, carried out the SSF fermentation experiments, participated in data analysis and interpretation, and drafted the manuscript. L.F. planned the study and the experimental design, carried out the yeast isolation, identification and fermenting vigour characterization, performed data analysis, participated in data interpretation, and revised the manuscript. L.C. participated in the planning of the study and SSF fermentation experiments, composed the graphical abstract, and commented on the manuscript. S.B. participated in fermenting vigour experiments. V.P. participated in SSF fermentation experiments. M.B. participated in data interpretation, and commented on the manuscript. S.C. participated in data interpretation, and commented on the manuscript. All authors read and approved the final manuscript.

Funding: This research was funded by University of Padova [grants GRIC120EG8, 60A08-0924/15, DOR1657411/16; DOR1715524/17, DOR1728499/17, DOR1824847/18; DOR1931153/19].

Acknowledgments: The Authors are grateful to Willem Heber van Zyl (University of Stellenbosch, South Africa) for providing S. cerevisiae M2n, HR4, V3, WL3 and YI30.

Conflicts of Interest: The authors declare no conflict of interest. 


\section{References}

1. Gupta, A.; Verma, J.P. Sustainable bio-ethanol production from agro-residues: A review. Renew. Sustain. Energy Rev. 2015, 41, 550-567. [CrossRef]

2. Lin, Y.; Tanaka, S. Ethanol fermentation from biomass resources: Current state and prospects. Appl. Microbiol. Biotechnol. 2016, 69, 627-642. [CrossRef]

3. Balat, M.; Balat, H.; Öz, C. Progress in bioethanol processing. Prog. Energy Combust. 2008, 34, 551-573. [CrossRef]

4. Mussatto, S.I.; Dragone, G.; Guimarães, P.M.; Silva, J.P.; Carneiro, L.M.; Roberto, I.C.; Vicente, A.; Domingues, L.; Teixeira, J.A. Technological trends, global market, and challenges of bio-ethanol production. Biotechnol. Adv. 2010, 28, 817-830. [CrossRef]

5. Ishizaki, H.; Hasumi, K. Ethanol production from biomass. In Research Approaches to Sustainable Biomass Systems; Tojo, S., Hirasawa, T., Eds.; Academic Press: Cambridge, MA, USA, 2014; pp. 243-258, ISBN 9780124046092.

6. Aditiya, H.B.; Mahlia, T.M.I.; Chong, W.T.; Nur, H.; Sebayang, A.H. Second generation bioethanol production: A critical review. Renew. Sustain. Energy Rev. 2016, 66, 631-653. [CrossRef]

7. Cesaro, A.; Belgiorno, V. Combined biogas and bioethanol production: Opportunities and challenges for industrial application. Energies 2015, 8, 8121-8144. [CrossRef]

8. Hossain, N.; Zaini, J.H.; Mahlia, T.M.I. A review of bioethanol production from plant-based waste biomass by yeast fermentation. Int. J. Technol. 2017, 8, 5. [CrossRef]

9. Zabed, H.; Sahu, J.N.; Suely, A.; Boyce, A.N.; Faruq, G. Bioethanol production from renewable sources: Current perspectives and technological progress. Renew. Sustain. Energy Rev. 2017, 71, 475-501. [CrossRef]

10. Saini, J.K.; Saini, R.; Tewari, L. Lignocellulosic agriculture wastes as biomass feedstocks for second-generation bioethanol production: Concepts and recent developments. 3 Biotech 2015, 5, 337-353. [CrossRef]

11. Bentivoglio, D.; Finco, A.; Bacchi, M.R.P. Interdependencies between biofuel, fuel and food prices: The case of the brazilian ethanol market. Energies 2016, 9, 464. [CrossRef]

12. Balat, M.; Ayar, G. Biomass energy in the world, use of biomass and potential trends. Energy Sources 2005, 27, 931-940. [CrossRef]

13. Alvira, P.; Tomàs-Pejò, E.; Ballesteros, M.; Negro, M.J. Pretreatment technologies for an efficient bioethanol production process based on enzymatic hydrolysis: A review. Bioresour. Technol. 2010, 101, 4851-4861. [CrossRef]

14. Romanelli, M.G.; Povolo, S.; Favaro, L.; Fontana, F.; Basaglia, M.; Casella, S. Engineering Delftia acidovorans DSM39 to produce polyhydroxyalkanoates from slaughterhouse waste. Int. J. Biol. Macromol. 2014, 71, $21-27$. [CrossRef]

15. Alibardi, L.; Green, K.; Favaro, L.; Vale, P.; Soares, A.; Cartmell, E.; Fernández, Y.B. Performance and stability of sewage sludge digestion under $\mathrm{CO}_{2}$ enrichment: A pilot study. Bioresour. Technol. 2017, 245, 581-589. [CrossRef]

16. Favaro, L.; Todorov, S.D. Bacteriocinogenic LAB strains for fermented meat preservation: Perspectives, challenges, and limitations. Probiot. Antimicrob. Proteins 2017, 9, 444-458. [CrossRef]

17. Campanaro, S.; Treu, L.; Kougias, P.G.; Luo, G.; Angelidaki, I. Metagenomic binning reveals the functional roles of core abundant microorganisms in twelve full-scale biogas plants. Water Res. 2018, 140, 123-134. [CrossRef]

18. Duan, N.; Ran, X.; Li, R.; Kougias, P.; Zhang, Y.; Lin, C.; Liu, H. Performance evaluation of mesophilic anaerobic digestion of chicken manure with algal digestate. Energies 2018, 11, 1829. [CrossRef]

19. Lantz, M.; Prade, T.; Ahlgren, S.; Björnsson, L. Biogas and Ethanol from wheat grain or straw: Is there a trade-off between climate impact, avoidance of iLUC and production cost? Energies 2018, 11, 2633. [CrossRef]

20. Favaro, L.; Basaglia, M.; Casella, S. Improving polyhydroxyalkanoate production from inexpensive carbon sources by genetic approaches: A review. Biofuels Bioprod. Biorefining 2019, 13, 208-227. [CrossRef]

21. Solomon, B.D.; Barnes, J.R.; Halvorsen, K.E. Grain and cellulosic ethanol: History, economics, and energy policy. Biomass Bioenergy 2007, 31, 416-425. [CrossRef]

22. Nitsos, C.; Rova, U.; Christakopoulos, P. Organosolv fractionation of softwood biomass for biofuel and biorefinery applications. Energies 2017, 11, 50. [CrossRef] 
23. Cripwell, R.; Favaro, L.; Rose, S.H.; Basaglia, M.; Cagnin, L.; Casella, S.; van Zyl, W.H. Utilization of wheat bran as a substrate for bioethanol production using recombinant cellulases and amylolytic yeast. Appl. Energy 2015, 160, 610-617. [CrossRef]

24. Favaro, L.; Cagnin, L.; Basaglia, M.; Pizzocchero, V.; van Zyl, W.H.; Casella, S. Production of bioethanol from multiple waste streams of rice milling. Bioresour. Technol. 2017, 244, 151-159. [CrossRef]

25. Olguin-Maciel, E.; Larqué-Saavedra, A.; Pérez-Brito, D.; Barahona-Pérez, L.F.; Alzate-Gaviria, L.; Toledano-Thompson, T.; Lappe-Oliveras, P.E.; Huchin-Poot, E.G.; Tapia-Tussell, R. Brosimum alicastrum as a novel starch source for bioethanol production. Energies 2017, 10, 1574. [CrossRef]

26. Pradyawong, S.; Juneja, A.; Sadiq, M.; Noomhorm, A.; Singh, V. Comparison of cassava starch with corn as a feedstock for bioethanol production. Energies 2018, 11, 3476. [CrossRef]

27. Ahorsu, R.; Medina, F.; Constantí, M. Significance and challenges of biomass as a suitable feedstock for bioenergy and biochemical production: A review. Energies 2018, 11, 3366. [CrossRef]

28. Nigam, P.; Singh, D. Enzyme and microbial systems involved in starch processing. Enzyme Microb. Technol. 1995, 17, 770-778. [CrossRef]

29. Castro, A.M.; Castilho, L.R.; Freire, D.M.G. An overview on advances of amylases production and their use in the production of bioethanol by conventional and non-conventional processes. Biomass Convers. Biorefinery 2011, 1, 245-255. [CrossRef]

30. Sánchez, Ó.J.; Cardona, C.A. Trends in biotechnological production of fuel ethanol from different feedstocks. Bioresour. Technol. 2008, 99, 5270-5295. [CrossRef]

31. Favaro, L.; Jooste, T.; Basaglia, M.; Rose, S.H.; Saayman, M.; Görgens, J.F.; Casella, S.; van Zyl, W.H. Designing industrial yeasts for the consolidated bioprocessing of starchy biomass to ethanol. Bioengineered 2013, 4, 97-102. [CrossRef]

32. Favaro, L.; Viktor, M.J.; Rose, M.H.; Bloom, M.V.; van Zyl, W.H.; Basaglia, M.; Cagnin, L.; Casella, S. Consolidated bioprocessing of starchy substrates into ethanol by industrial Saccharomyces cerevisiae strains secreting fungal amylases. Biotechnol. Bioeng. 2015, 112, 1751-1760. [CrossRef]

33. Lynd, L.R.; van Zyl, W.H.; McBride, J.E.; Laser, M. Consolidated bioprocessing of cellulosic biomass: An update. Curr. Opin. Biotechnol. 2005, 16, 577-583. [CrossRef]

34. Favaro, L.; Jooste, T.; Basaglia, M.; Rose, S.H.; Saayman, M.; Görgens, J.F.; Casella, S.; van Zyl, W.H. Codon-optimized glucoamylase sGAI of Aspergillus awamori improves starch utilization in an industrial yeast. Appl. Microbiol. Biotechnol. 2012, 95, 957-968. [CrossRef]

35. van Zyl, W.H.; Bloom, M.; Viktor, M.J. Engineering yeasts for raw starch conversion. Appl. Microbiol. Biotechnol. 2012, 95, 1377-1388. [CrossRef]

36. Cripwell, R.A.; Rose, S.H.; van Zyl, W.H. Expression and comparison of codon optimised Aspergillus tubingensis amylase variants in Saccharomyces cerevisiae. FEMS Yeast Res. 2017, 17. [CrossRef]

37. Walker, G.M.; Walker, R.S.K. Enhancing yeast alcoholic fermentations. Adv. Appl. Microbiol. 2018, 105, 87-129. [CrossRef]

38. Bothast, R.J.; Schlicher, M.A. Biotechnological processes for conversion of corn into ethanol. Appl. Microbiol. Biotechnol. 2005, 67, 19-25. [CrossRef]

39. Görgens, J.F.; Bressler, D.C.; van Rensburg, E. Engineering Saccharomyces cerevisiae for direct conversion of raw, uncooked or granular starch to ethanol. Crit. Rev. Biotechnol. 2014, 8551, 1-23. [CrossRef]

40. Mohd Esa, N.; Ling, T.B. By-products of rice processing: An overview of health benefits and applications. Rice Res. Open Access 2016, 4, 1-11. [CrossRef]

41. Favaro, L.; Basaglia, M.; Trento, A.; Van Rensburg, E.; García-Aparicio, M.; van Zyl, W.H.; Casella, S. Exploring grape marc as trove for new thermotolerant and inhibitor-tolerant Saccharomyces cerevisiae strains for second-generation bioethanol production. Biotechnol. Biofuels 2013, 6, 168. [CrossRef]

42. Favaro, L.; Basaglia, M.; van Zyl, W.H.; Casella, S. Using an efficient fermenting yeast enhances ethanol production from unfiltered wheat bran hydrolysates. Appl. Energy 2013, 102, 170-178. [CrossRef]

43. Jansen, T.; Hoff, J.W.; Jolly, N.; van Zyl, W.H. Mating of natural Saccharomyces cerevisiae strains for improved glucose fermentation and lignocellulosic inhibitor tolerance. Folia Microbiol. 2018, 63, 55-68. [CrossRef]

44. He, L.; Zhao, X.; Bai, F. Engineering industrial Saccharomyces cerevisiae strain with the FLO1-derivative gene isolated from the flocculating yeast SPSC01 for constitutive flocculation and fuel ethanol production. Appl. Energy 2012, 100, 33-40. [CrossRef] 
45. Ortiz-Muñiz, B.; Carvajal-Zarrabal, O.; Torrestiana-Sanchez, B.; Aguilar-Uscanga, M.G. Kinetic study on ethanol production using Saccharomyces cerevisiae ITV-01 yeast isolated from sugar cane molasses. J. Chem. Technol. Biotechnol. 2010, 85, 1361-1367. [CrossRef]

46. Hahn-Hägerdal, B.; Karhumaa, K.; Larsson, C.U.; Gorwa-Grauslund, M.; Görgens, J.; van Zyl, W.H. Role of cultivation media in the development of yeast strains for large scale industrial use. Microb. Cell Fact. 2005, 4, 31. [CrossRef]

47. Dahod, S.K. Raw material selection and medium development for industrial fermentation processes. In Manual of Industrial Microbiology and Biotechnology, 2nd ed.; Demain, A.L., Davies, J.E., Eds.; ASM Press: Washington, DC, USA, 1999; pp. 213-220, ISBN 9781555815127.

48. Borglum, G.B. Starch hydrolysis for ethanol production. Am. Chem. Soc. Div. Fuel Chem. 1980, 25, $264-269$.

49. Ribéreau-Gayon, P.; Dubourdieu, D.; Donèche, B.; Lonvaud, A. Handbook of Enology, Volume 1: The Microbiology of Wine and Vinifications, 2nd ed.; John Wiley \& Sons, Ltd.: Chichester, UK, 2006; ISBN 9780470010365.

50. Zhang, L.; Zhao, H.; Gan, M.; Jin, Y.; Gao, X.; Chen, Q.; Guan, J.; Wang, Z. Application of simultaneous saccharification and fermentation (SSF) from viscosity reducing of raw sweet potato for bioethanol production at laboratory, pilot and industrial scales. Bioresour. Technol. 2011, 102, 4573-4579. [CrossRef]

51. Schmidt, F.R. Optimization and scale up of industrial fermentation processes. Appl. Microbiol. Biotechnol. 2005, 68, 425-435. [CrossRef]

52. Chu-Ky, S.; Pham, T.H.; Bui, K.L.T.; Nguyen, T.T.; Pham, K.D.; Nguyen, H.D.T.; Luong, H.N.; Tu, V.D.; Nguyen, T.H.; Ho, P.H.; et al. Simultaneous liquefaction, saccharification and fermentation at very high gravity of rice at pilot scale for potable ethanol production and distillers dried grains composition. Food Bioprod. Process. 2016, 98, 79-85. [CrossRef]

53. Horwitz, W.; Senzel, A.; Reynolds, H.; Park, D.L. Official Methods of Analysis of the Association of Official Analytical Chemists, 12th ed.; Association of Official Analytical Chemists: Washington, DC, USA, 1975.

54. Kurtzman, C.P.; Robnett, C.J. Identification and phylogeny of ascomycetous yeasts from analysis of nuclear large subunit (26S) ribosomal DNA partial sequences. Int. J. Gen. Mol. Microb. 1998, 73, 331-371. [CrossRef]

55. Delfini, C. Scienza e Tecnica di Microbiologia Enologica; Edizione: Il lievito, Asti, 1995.

56. Zaldivar, J.; Nielsen, J.; Olsson, L. Fuel ethanol production from lignocellulose: A challenge for metabolic engineering and process integration. Appl. Microbiol. Biotechnol. 2001, 56, 17-34. [CrossRef]

57. Hamelinck, C.; Van Hooijdonk, G.; Faaij, A. Ethanol from lignocellulosic biomass: Techno-economic performance in short-, middle- and long-term. Biomass Bioenergy 2005, 28, 384-410. [CrossRef]

58. Cagnin, L.; Favaro, L.; Gronchi, N.; Rose, S.H.; Basaglia, M.; van Zyl, W.H.; Casella, S. Comparing laboratory and industrial yeast platforms for the direct conversion of cellobiose into ethanol under simulated industrial conditions. FEMS Yeast Res. 2019, foz018. [CrossRef]

(C) 2019 by the authors. Licensee MDPI, Basel, Switzerland. This article is an open access article distributed under the terms and conditions of the Creative Commons Attribution (CC BY) license (http://creativecommons.org/licenses/by/4.0/). 